\title{
Knowledge Management - a Fostering Tool for Parallel Outlines among Public \& Private Sector Banks
}

\author{
V. Kuppulakshmi, S. Manikandan, M. Kavitha
}

\begin{abstract}
In this global Scenario, Banking sector has gone throughdrastictechnological changes. Customer Knowledge plays a crucial role in the banking sector. To achieve the operational efficiency, customer knowledge management (CKM) techniques support the banks to move forward. Banks need a well-organized database to facilitate the availability of information to their customers. Hence focus should be made on CKM practices which include Knowledge Gathering, Storing, Transferring and Utilizing the Customer Knowledge, ideas, information and experiences. Knowledge Gathering includes the study of customers' priority and needs. Knowledge storing can be done by way of knowledge repository, updating and retrieval of information. Knowledge transferring comprises of providing data to clients regarding new schemes and services. It distributes the knowledge throughout the organization. Knowledge utilizing can be made by way of quick access of knowledge about the customers to meet out their priorities. Thus, the CKM process will enable the banks to maintain better relationship with their customers.
\end{abstract}

Keywords : Knowledge Management, Customer Knowledge Management (CKM), Knowledge Gathering, Knowledge storing, Knowledge transferring, Knowledge utilizing, Customer Relationship Management.

\section{INTRODUCTION}

P resent day organizations, especially, the banks are undergoing intense competition as a result of the increasing globalization and the resultant market pressure. Knowledge management dominates all disciplines in most of the organization. Therefore, organizations must effectively manage their knowledge to attain competitive efficiency. The progression of managing knowledge is called Knowledge Management (KM) or sometimes known as Business Intelligence (BI). Knowledge Management enables organizations to discover, select, arrange, transfer and disseminate significant information and ability required for activities, for example, critical thinking, dynamic learning, decision - making and strategic planning.

Revised Manuscript Received on December 05, 2019.

* Correspondence Author

Ms. V. Kuppulakshmi*, Research Scholar, Guru Nanak College(Autonomous), Chennai, India.

Dr. S. Manikandan, Associate Professor, Research Supervisor, PG \& Research Department of Commerce, Guru Nanak College (Autonomous), Chennai, India.

Dr. M. Kavitha, Assistant Professor, Research Supervisor, PG \& Research Department of Commerce, Guru Nanak College (Autonomous), Chennai, India

\section{REVIEW OF LITERATURE}

Customer learning ability helps in, creating and coordinating client data all through the organisation (Alexandra J. Campbell,2011). (Attafar Ali et al 2013) stated that Knowledge Management incorporates usage and support of the organisational and technical foundations or infrastructure. Organisation must appreciate both implicit and explicit information to control the data and they need to offer right information cycle of available knowledge. Customer Knowledge management allow the organization to take the best needed customer knowledge for proper decision. This decision process gaining more knowledge from customers and use it for their business processes. Many companies can directly make personal interaction with customers to know their preferences and needs (Narges Sharifi Tehrani et al 2015). Establishment of technological and informational infrastructure allow organizations to better understand the knowledge about customers (Graeme Shanks and Emily Tay 2001).

\section{OBJECTIVES}

The major objectives are

- Studying the Customer Knowledge Management Practices in the banking sector.

- Making a relative study about the Public and Private sector banks on CKM practices

- Measuring the Business Performance of the banks.

\section{AN OVERVIEW OF CKM IN BANKING SECTOR}

Knowledge is considered as a fundamental key asset that empowers firms to continue an upper hand in a modern environment (Grand, 1996 \& Spender, 1998). Knowledge management in business firms need to deal with the exercises of knowledge workers and cooperation of organizational static and dynamic knowledge about products, administration, services, process development, simultaneously, making new or existing organizational information. 
The motivation behind knowledge management is to make a typical space for people to interact for trading and making learning. Customer Knowledge Management (CKM) is another methodology embraced by the organizations where all the details, data, experiences, information and knowledge are collected from the client and every one of these things are used by the organizations for the procedures of the business. A process that changes individual information to organizational information is termed as customer knowledge management. The procedure of knowledge gathering, storing, transferring and utilization ends up essential and banks monitor and deal with these basic procedures. The most well- known fields of knowledge management in a bank are risk administration, marketing management, customer relationship management and performance appraisal particularly to help its stakeholders. Customer knowledge management can cause many advantages like better decision - making, problem solving, improved customer management and expanding profit.

Gathering Customer Knowledge (GCK) process getting to know the customer needs and their preferences. Collection of customer information will help the employees to know their requirements and offer better products and services.

After gathering the customer knowledge, the customer details are stored by using proper database. We can store the information about transaction per customer for easy access and retrieval of each customer. This process is known as Storing Customer Knowledge (SCK).

Transferring Customer Knowledge (TCK) process would be done with the help of storage of customer information. This will aid to find the customer preferences and their immediate need. Knowledge repository facilitates sharing of knowledge about new products and services. This process will support the customer to make a right decision in their particular situation.

Utilizing Customer Knowledge (UKC) make better organization which identify customers better and eventually expressed using customer knowledge management. Utilization of customer knowledge give an opportunity before their competitors and at the same time attract new customers.

Business Performance (BP) is the process by which the company handles the best way to achieve its goals. Selection of goals, interference and integration activity work together to initiate effective process in the organization.

\section{METHODOLOGY}

The study was conducted through purposive sampling technique and constructed a questionnaire to collect data from 80 bank employees. Questions related to customer knowledge management and business performance were asked to meet the objectives of the study.

\section{ANALYSIS \& INTERPRETATION}

The demographic details reveal that majority of $55 \%$ of employees are male in public sector bank and $57.5 \%$ in private sector banks as against $45 \%$ female employees in public and $42.5 \%$ in private sector. $37.5 \%$ of the employees are falling in the age of 20 years -30 years in public sector and $35 \%$ of them are in private sector. Under educational background $50 \%$ of the respondents hold $\mathrm{PG}$ in public sector and $55 \%$ of them in private sector banks. $47.5 \%$ of the respondents hold senior level in public and $52.5 \%$ holds in private sector. A major portion of $35 \%$ of the respondents getting up to 55000 income in public sector and $32.5 \%$ of them getting above 70000 income private sector banks.

Table - 1: Descriptive Statistics

\begin{tabular}{|c|c|c|c|c|c|}
\hline \multicolumn{6}{|c|}{ DESCRIPTINE STATISTICS } \\
\hline \multirow[t]{2}{*}{ ELEMENTS } & \multirow[t]{2}{*}{ CATEGORY } & \multicolumn{2}{|c|}{ PUBLC SECTOR } & \multicolumn{2}{|c|}{ PRNATE SECTOR } \\
\hline & & Frequency & Percentage & Frequency & Percentage \\
\hline \multirow[t]{2}{*}{ GENDER } & Male & 22 & $55 \%$ & 23 & $57.5 \%$ \\
\hline & Female & 18 & $45 \%$ & 17 & $425 \%$ \\
\hline TOTAL & & 40 & $100 \%$ & 40 & $100 \%$ \\
\hline \multirow[t]{4}{*}{ AGE } & 21-30 Years & 15 & $37.5 \%$ & 14 & $35 \%$ \\
\hline & 31-40 Years & 13 & $32.5 \%$ & 10 & $25 \%$ \\
\hline & 41-50 Years & 8 & $20.0 \%$ & 9 & $22.5 \%$ \\
\hline & SOabove & 4 & $10.0 \%$ & 7 & $17.5 \%$ \\
\hline TOTAL & & 40 & $100 \%$ & 40 & $100 \%$ \\
\hline EDUCATKONAL & UG & 12 & $30 \%$ & 11 & $27.5 \%$ \\
\hline \multirow[t]{2}{*}{ BACKGROUND } & PG & 20 & $50 \%$ & 22 & $55 \%$ \\
\hline & PROFESSIONAL & 8 & $20 \%$ & 7 & $17.5 \%$ \\
\hline TOTAL & & 40 & $100 \%$ & 40 & $100 \%$ \\
\hline \multirow[t]{2}{*}{ DESIGNATKON } & Senior level & 19 & $47.5 \%$ & 21 & $52.5 \%$ \\
\hline & Middle level & 21 & $52.5 \%$ & 19 & $47.5 \%$ \\
\hline TOTAL & & 40 & $100 \%$ & 40 & $100 \%$ \\
\hline \multirow[t]{4}{*}{ INCOME } & $25000-40000$ & 7 & $17.5 \%$ & 10 & $25 \%$ \\
\hline & $40000-55000$ & 14 & $35 \%$ & 9 & $22.5 \%$ \\
\hline & $55000-70000$ & 6 & $15 \%$ & 8 & $20 \%$ \\
\hline & 7o000above & 13 & $32.5 \%$ & 13 & $32.5 \%$ \\
\hline TOTAL & & 40 & $100 \%$ & 40 & $100 \%$ \\
\hline
\end{tabular}




\section{ANALYSIS ON CKM PRACTICES}

Table - 2

\begin{tabular}{|c|c|c|c|c|}
\hline Variable & NOB & Agree & $\begin{array}{c}\text { Strongly } \\
\text { Agree }\end{array}$ & $\begin{array}{c}\text { Asymptotic } \\
\text { Significance } \\
\text { Value }\end{array}$ \\
\hline \multicolumn{5}{|l|}{ GCK } \\
\hline \multirow[b]{2}{*}{$\begin{array}{l}\mathrm{H} 1 \text { : There is a } \\
\text { significant } \\
\text { association between } \\
\text { NOB and GCK }\end{array}$} & Public & 10 & 30 & \multirow[b]{2}{*}{$\begin{array}{c}.000^{* *} \\
\text { Null } \\
\text { Hypothesis } \\
\text { Is rejected }\end{array}$} \\
\hline & Private & 13 & 27 & \\
\hline \multicolumn{5}{|l|}{ SCK } \\
\hline \multirow{2}{*}{$\begin{array}{l}\mathrm{H} 2: \text { There is a } \\
\text { significant } \\
\text { association between } \\
\text { NOB and SCK }\end{array}$} & Public & 10 & 30 & \multirow{2}{*}{$\begin{array}{c}.000^{* *} \\
\text { Null } \\
\text { Hypothesis } \\
\text { Is rejected }\end{array}$} \\
\hline & Private & 11 & 29 & \\
\hline \multicolumn{5}{|l|}{ TCK } \\
\hline \multirow{2}{*}{$\begin{array}{l}\quad \text { H3: There is a } \\
\text { Significant } \\
\text { association between } \\
\text { NOB and TCK }\end{array}$} & Public & 13 & 27 & \multirow{2}{*}{$\begin{array}{c}.000^{* *} \\
\text { Null } \\
\text { Hypothesis } \\
\text { Is rejected }\end{array}$} \\
\hline & Private & 15 & 25 & \\
\hline \multicolumn{5}{|l|}{ UCK } \\
\hline \multirow{2}{*}{$\begin{array}{l}\text { H4: There is a } \\
\text { significant } \\
\text { association between } \\
\text { NOB and UCK }\end{array}$} & Public & 20 & 20 & \multirow{2}{*}{$\begin{array}{c}.000^{* * *} \\
\text { Null } \\
\text { Hypothesis } \\
\text { Is rejected }\end{array}$} \\
\hline & Private & 14 & 26 & \\
\hline & $\begin{array}{l}\text { ote: *** } \\
\text { NO }\end{array}$ & $\begin{array}{l}0.01 \mathrm{~s} \\
\text { Natur }\end{array}$ & $\begin{array}{l}1 \% \text { level } \\
\text { 3anks }\end{array}$ & \\
\hline
\end{tabular}

By applying Chi-square test it is seen that the $\mathrm{p}$ value is 0.000 , null hypothesis is rejected. It can be concluded that the customer knowledge management practices (GCK, SCK, TCK, UCK) has significant influence on nature of banks.

\section{ANALYSIS OF BUSINESS PERFORMANCE}

Table - 3: Analysis of Variance

\begin{tabular}{|l|l|c|c|c|c|c|}
\hline \multicolumn{2}{|c|}{} & $\begin{array}{c}\text { Sum of } \\
\text { Squares }\end{array}$ & df & $\begin{array}{c}\text { Mean } \\
\text { Square }\end{array}$ & F & Sig. \\
\hline \multirow{5}{*}{ GCK } & Between Groups & 1.016 & 1 & .016 & 5.842 & .000 \\
\cline { 2 - 8 } & Within Groups & 15.372 & 78 & .210 & & \\
\cline { 2 - 8 } & Total & 16.387 & 79 & & & \\
\hline \multirow{5}{*}{ SCK } & Between Groups & 1.190 & 1 & .190 & 5.341 & .000 \\
\cline { 2 - 8 } & Within Groups & 14.298 & 78 & .196 & & \\
\cline { 2 - 8 } & Total & 15.488 & 79 & & & .000 \\
\hline \multirow{5}{*}{ TCK } & Between Groups & 1.251 & 1 & .251 & 6.707 & \\
\cline { 2 - 8 } & Within Groups & 16.949 & 78 & .230 & & \\
\cline { 2 - 8 } & Total & 18.200 & 79 & & & \\
\hline \multirow{5}{*}{ UCK } & Between Groups & 9.556 & 1 & 9.556 & 3.520 & .008 \\
\cline { 2 - 8 } & Within Groups & 9.994 & 78 & .128 & & \\
\hline & Total & 19.550 & 79 & & & \\
\hline
\end{tabular}

At $95 \%$ confident interval it describes that, there is significant influence of GCK by one-way ANOVA (F $(1,78)$
$=5.484, \mathrm{p}=.000)$ for Business performance.

At $95 \%$ confident interval it describes that, there is significant influence of SCK by one-way ANOVA $(F(1,78)=$ $5.484, \mathrm{p}=.000)$ for Business performance.

At $95 \%$ confident interval it describes that, there is significant influence of TCK by one-way ANOVA $(\mathrm{F}(1,78)$ $=5.484, \mathrm{p}=.000$ ) for Business performance.

At $95 \%$ confident interval it describes that, there is significant influence of UCK by one-way ANOVA (F $(1,78)$ $=5.484, \mathrm{p}=.000)$ for Business performance.

\section{SUGGESTIONS AND RECOMMENDATIONS}

Customer knowledge management is essential in the banking sector and provides valuable information to retain the existing and maintaining new customers. Gaining knowledge from the customers revive the variety of products and services and rise the customer loyalty.Appropriate utilization of knowledge promotes new products within the short period of time. Capturing of customer interaction by the front-end's units such as customer care, knowledge repository and capturing customer segmentation are requisite to store the customer knowledge will be sure for future use.

\section{CONCLUSION}

Customer knowledge management practices are followed by many sectors like banking, insurance, transportation and hospitality. Customer knowledge management is an indispensable part of the banking sector. Customer data greatly facilitate sharing of new policies and activities with the banking sector. So, it is concluded that managing the knowledge of customers is a fostering tool for the sustainable growth and development of the banking sector.

\section{REFERENCES}

1. Campbell, A.J., "Creating Customer Knowledge Competence: Managing customer relationship management process strategically", Industria Marketing Management, 32, 2011, pp.375 - 383.

2. Zanjani, M.S., Rouzbehai, R., "Proposing a conceptual model of CKM: A study of CKM tools in British Dotcoms", IJEME, Volume-II, Number -II, 2011, pages 51-55.

3. Attafar, A., Shahin, A., "The Role of Customer Knowledge Management in improving organization - customer relationship", Middle-East Journal of Scientific Research, 2013, 13(16).

4. M.R. Grant, "Toward a Knowledge based theory of the firm, Strategic Management Journal, 1996, 17, S2, 109-122.

5. Paquette, R.S., "Knowledge Management System and customer knowledge use in organization's (Doctoral Dissertation) 


\section{AUTHORS PROFILE}

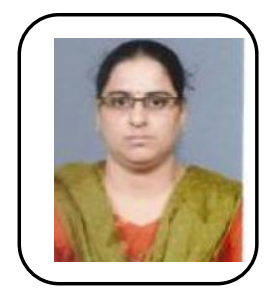

Mrs. V. Kuppulakshmi, is currently pursuing her Ph.D. in Guru Nanak College (Autonomous) under the guidance of Dr. M. Kavitha, Asst. Prof. of Commerce. She holds Triple Masters Viz., M.Com., MBA (Banking and Finance) and MA (Personnel Management \& Industrial Relations) and has completed her M.Phil from PRIST university. She is a Post Graduate Diploma holder in Educational Administration and Supervision. To her credit, she published \& presented her research Papers entitled "A Study on Knowledge management and its impact on Corporate sectors", "A Study on Green Human Resource Management Practices in Hotel Industry" and "An empirical study on Knowledge Creation \& Knowledge sharing practices in Automobile Industry" . She attended various workshops relating to research. Participated in many National and International Conferences.

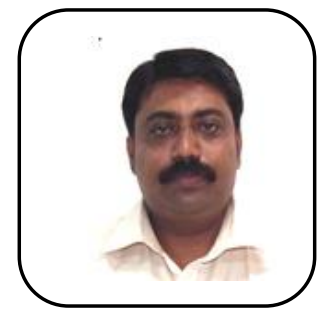

Dr. S. Manikandan, M.Com. M.Ed., M.Phil, Ph.D., qualified with SLET is an Associate Professor in the PG \& Research Department of Commerce., Guru Nanak College (Autonomous). He has 25 years of rich and varied experience in educating UG and PG students. He is a renowned Research Supervisor, Doctoral Committee Member and External Examiner of Ph.D. Viva Voce examinations and guiding $8 \mathrm{Ph} . \mathrm{D}$ scholars and one candidate has been awarded. He is an exclusive author having more chronicles to his list namely Financial Accounting, Cost Accounting and Management Accounting which are so prevalent and widespread in the educational field. He is the Editor and Reviewer of many journals. He published more than 50 research articles in several leading Journals with High Impact Factor and presented papers in National and International Conferences. He is applauded for his many invited talks and lectures at various Colleges and Universities in National and International Conferences as a Resource Person and a Chair Person. He received 2 Honours and 3 Awards as the recognition of his valuable contribution in the field of education and research. He obtained and successfully completed a Major Project from UGC. He is the Co-Ordinator of IQAC, Vice President of Students' Council, Convener and Member in various committees of Guru Nanak College.

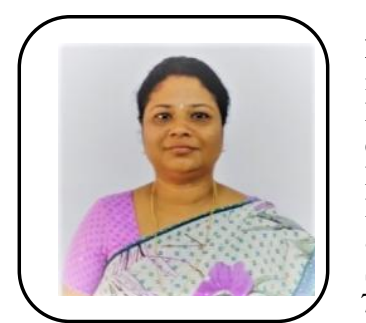

Dr.M.Kavitha, M.Com. MBA, M.Phil, Ph.D. is serving as an Assistant Professor in Guru Nanak College (Autonomous),Chennai and qualified SET in Commerce and SET in Management with 15 years of UG, 11 years of PG Teaching and research experience (Masters and Doctorate Level). Recognized Research Supervisor of University of Madras. Currently 7 candidates are pursuing their Ph.D. under her guidance. Evaluator of academic projects and trainer for FDP. She has experience in providing coaching for Soft skills and Personality development programmes for UG and PG students. She is an Academic counsellor, Project Guide and Evaluator of IGNOU, Board of examiners of University of Madras and other universities and autonomous colleges. Executive Editor of Guru Nanak Journal of Multi-Disciplinary Research- special issues. To her credit she published more than 50 articles in reputed journals and conference volume proceedings, participated and presented several papers in many national and international conferences. She has successfully completed the ARPIT course of MHRD. She is a Women-in-charge of commerce department and Department Co- ordinator of IQAC. Organizing committee member of national and international conferences and serving as member in several committees and event organizer of various academic programmes. 